Pengaruh Kecerdasan Emosional, Komunikasi, Dan ... (Romantik dan Hermin)

\title{
PENGARUH KECERDASAN EMOSIONAL, KOMUNIKASI, DAN LINGKUNGAN KERJA TERHADAP KINERJA PEGAWAI NEGERI PADA KANTOR PELAYANAN PUBLIK DI KABUPATEN PURBALINGGA
}

\author{
Romantik Citra Impiansi \\ Universitas Muhamamdiyah Purwokerto
}

Hermin Endratno

Universitas Muhamamdiyah Purwokerto

\begin{abstract}
The study was aimed to find out whether or not the emotional intelligence, communication, and working environment individually have a significant effect to the work performance of the civil servants. The respondents in the study were all the state servants working in three public service offices, including the Office of Integrated Investement and Business Permits, the Vehicle-Tax Payment Office (Samsat), and the Office of Population and Civil Administration. The sampling method was a saturated sampling.

The data were analyzed using multiple linear regression. Based on the result of analysis, it could be concluded that the variables of emotional intelligence, and working environment individually have no significant effect to the work performance of the employees. One variable having a significant effect on the work performance among the civil servants is the communication. However, the three variables simultenaously have significant effects to their performance. From the findings, it is suggested that the offices should explore more deeply the emotional intelligence, communication, and the working environment to improve their staffs.
\end{abstract}

Keywords: emotional intelligence, communication, working environment, work performance.

pemerintah untuk memenuhi kebutuhannya tersebut.Oleh karena itu, pemerintah perlu meningkatkan kualitas pelayanan melalui Sumber Daya Manusia yang matang, sehingga kinerja dari tenaga kerja menghasilkan kinerja yang baik dan memiliki kesan yang menyenangkan serta citra positif di mata masyarakat.Seperti halnya pada Kantor Penanaman Modal dan Perizinan Terpadu, Samsat, dan Dinas Kependudukan dan Pencatatan Sipil Kabupaten Purbalingga yang terus memperbaiki pelayanan terhadap masyarakat demi mencapai tujuan kinerja yang semakin baik. 
Dalam meningkatkan kinerja pegawai kantor pelayanan publik perlu memperhatikan beberapa cara misalnya melalui kecerdasan emosional yang dimiliki setiap individu, komunikasi yang bisa menumbuhkan hubungan yang baik, dan lingkungan kerja yang kondusif. Melalui proses-proses tersebut, pegawai diharapkan akan lebih memaksimalkan tanggung jawab atas pekerjaan mereka.

Berdasarkan latar belakang diatas, maka penulis mengambil judul "Pengaruh Kecerdasan Emosional, Komunikasi, dan Lingkungan Kerja Terhadap Kinerja Pegawai Negeri Pada Kantor Pelayanan Publik Di Kabupaten Purbalingga". Penelitian ini bertujuan untuk; 1) mengetahui pengaruh positif kecerdasan emosional terhadap kinerja pegawai ketiga kantor pelayanan publik (KPMPT, SAMSAT, dan DISPENDUKCAPIL) di Kabupaten Purbalingga; 2) Untuk mengetahui pengaruh positif komunikasi terhadap kinerja pegawai ketiga kantor pelayanan publik (KPMPT, SAMSAT, dan DISPENDUKCAPIL) di Kabupaten Purbalingga; 3) Untuk mengetahui pengaruh positif lingkungan kerja terhadap kinerja pegawai ketiga kantor pelayanan publik (KPMPT, SAMSAT, dan DISPENDUKCAPIL) di Kabupaten Purbalingga; 4) Untuk mengetahui pengaruh positif kecerdasan emosional, komunikasi, dan lingkungan kerja secara bersama-sama terhadap kinerja pegawai ketiga kantor pelayanan publik (KPMPT, SAMSAT, dan DISPENDUKCAPIL) di Kabupaten Purbalingga.

\section{B. TINJAUAN PUSTAKA}

Menurut Mangkunegara (2007) kinerja adalah hasil kerja secara kualitas dan kuantitas yang dicapai oleh seseorang pegawai dalam melaksanakan tugasnya sesuai dengan tanggung jawab yang diberikan kepadanya. Kinerja dinyatakan baik dan sukses jika tujuan yang diinginkan dapat tercapai dengan baik (Gibson dan Ivancevich,1994). Agar dapat memperoleh kinerja yang baik, diperlukan kualitas sumber daya manusia yang baik pula (Campbell dkk dalam Cascio,1998).

Peningkatan kinerja tentu saja tidak lepas dari faktor-faktor yang mempengaruhinya. Terkait dengan faktor-faktor yang mempengaruhi kinerja, Winardi (1996) mengemukakan bahwa faktor-faktor tersebut dapat dikelompokkan menjadi dua, yaitu faktor intrinsik (motivasi, pendidikan, kemampuan, keterampilan dan pengetahuan) dan faktor ekstrinsik (lingkungan kerja, kepemimpinan, hubungan kerja, dan gaji). 


\section{Pengaruh Kecerdasan Emosional terhadap Kinerja Pegawai}

Menurut Golemen (2003) kecerdasan emosional adalah kemampuan lebih yang dimiliki seseorang dalam memotivasi diri, ketahanan dalam menghadapi kegagalan, mengendalikan emosi, dan menunda kepuasan serta mengatur keadaan jiwa.Koordinasi suasana hati menurut Golemen (1998) adalah inti dari hubungan sosial yang baik. Apabila seseorang pandai menyesuaikan diri dengan suasana hati individu yang lain atau dapat berempati, orang tersebut akan memiliki tingkat emosionalitas yang baik dan akan lebih mudah menyesuaikan diri dalam pergaulan sosial. Sedangkan menurut Salovey dan Mayer (1990), kecerdasan emosional sebagai kemampuan untuk mengenali perasaan, meraih dan membangkitkan perasaan untuk membantu pikiran, memahami perasaan dan maknanya, dan mengendalikan perasaan secara mendalam sehingga dapat membantu perkembangan emosi dan intelektual.

Penelitian Iman (2004), Kecerdasan Emosional bukanlah merupakan suatu hal yang bersifat dimensi tunggal semata, yang hanya bisa diukur dari satu sisi dimensi saja, dimensi intelegensi. Kesuksesan manusia dan juga kebahagiannya, ternyata lebih terkait dengan kecerdasan selain IQ.Menurut hasil penelitiannya, setidaknya $75 \%$ kesuksesan manusia lebih ditentukan oleh kecerdasan emosionalnya dan hanya $4 \%$ yang ditentukan oleh kecerdasan intelektualnya. Berdasarkan uraian diatas dapat ditarik hipotesis sebagai berikut:

Hipotesis pertama : Kecerdasan Emosional berpengaruh secara positif terhadap kinerja pegawai negeri pada kantor pelayanan publik.

\section{Pengaruh Komunikasi Terhadap Kinerja}

Menurut Robbins (2006) bahwa komunikasi adalah proses penyampaian informasi, gagasan, fakta, pikiran dan perasaan dari satu orang ke orang lain. Dalam kehidupan organisasi, komunikasi menjadi sesuatu yang sangat penting karena komunikasi dapat meningkatkan saling pengertian antara atasan dan bawahan dalam hal ini pegawai dan pimpinan, dan meningkatkan koordinasi dari berbagai macam kegiatan atau tugas yang berbeda.

Penelitian Partini (2011) dengan judul Pengaruh Komunikasi, Kepemimpinan, dan Kedisiplinan Kerja Terhadap Kinerja Karyawan, variabel komunikasi mempunyai pengaruh paling dominan ditunjukkan dengan koefisien regresi paling tinggi. Berdasarkan uraian diatas dapat ditarik hipotesis sebagai berikut:

Hipotesis Kedua: Komunikasi berpengaruh secara positif terhadap kinerja pegawai negeri pada kantor pelayanan publik.

\section{Pengaruh Lingkungan Kerja Terhadap Kinerja}

Pembentukan lingkungan kerja yang mendukung kinerja akan menimbulkan kepuasan kerja bagi pekerja dalam suatu organisasi (Kegan,1993).Hendiana dalam Ishak dan Hendri (2004) mengatakan bahwa Penciptaan lingkungan kerja yang menyenangkan dan dapat memenuhi 
kebutuhan pegawai akan memberikan rasa puas dan mendorong semangat kerja mereka. Dengan lingkungan kerja yang baik dan nyaman, para pekerja akan dapat bekerja dengan baik tanpa adanya gangguan-gangguan yang berarti.

Penelitian Setyaningsih (2010) dengan judul Pengaruh Kepemimpinan, Motivasi, Komunikasi, Dan Lingkungan Kerja Terhadap Terhadap Kinerja Pegawai, menemukan bukti bahwa variabel lingkungan kerja memiliki pengaruh yang positif dan signifikan terhadap kinerja pegawai. Apabila lingkungan kerja ditingkatkan, maka kinerja pegawai semakin meningkat dengan asumsi variabel kepemimpinan, motivasi, dan lingkungan kerja dianggap konstan.Berdasarkan uraian diatas ditarik hipotesis sebagai dapat berikut:

Hipotesis Ketiga: Lingkungan Kerja berpengaruh secara positif terhadap kinerja pegawai negeri pada kantor pelayanan publik.

\section{KERANGKA PEMIKIRAN}

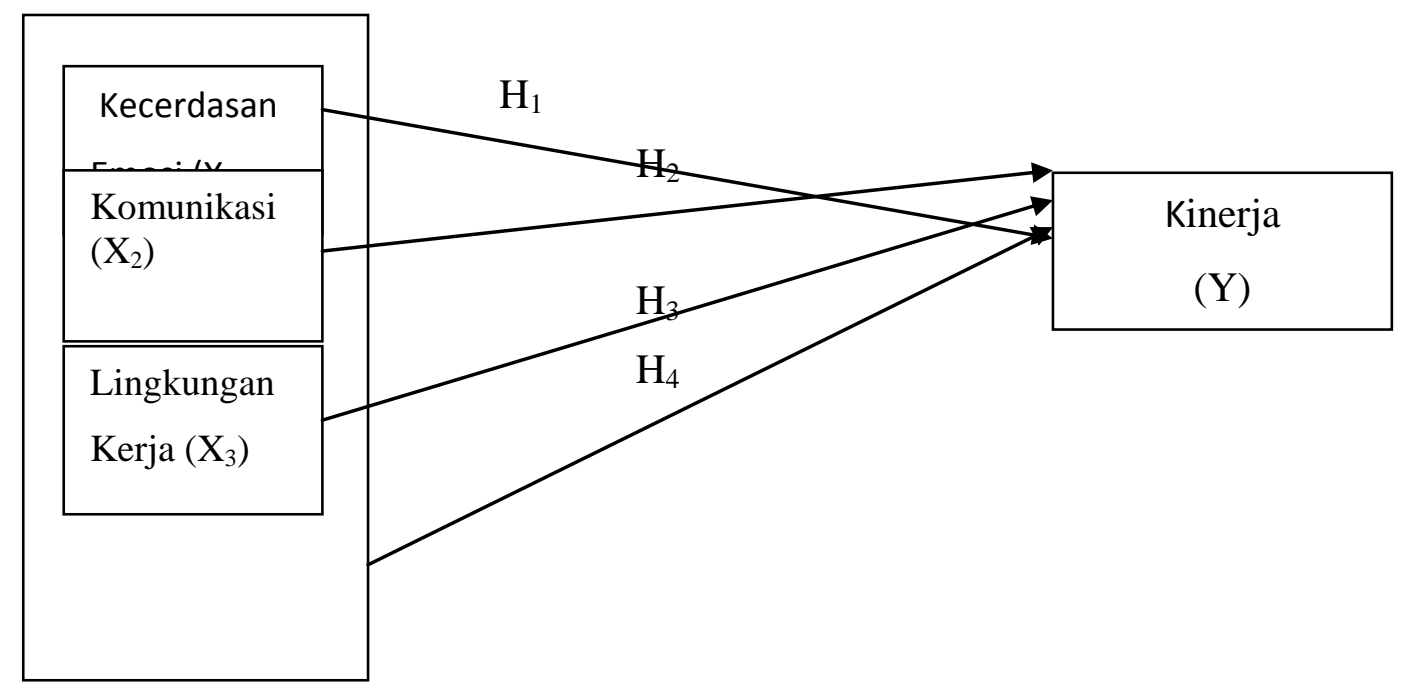




\section{METODE PENELITIAN}

Penelitian ini dilaksanakan di Ketiga Kantor Pelayanan Publik yaitu Kantor Penanaman Modal dan Perizinan Terpadu, Samsat, dan Dinas Kependudukan dan Pencatatan Sipil Kabupaten Purbalingga. Populasi penelitian iniadalah ketiga kantor pelayanan publik. Ukuran sampel menggunakan sampel jenuh/sensus dengan jumlah keseluruhan yaitu 85 responden. Teknik analisis data menggunakan analisis regresi linear berganda.

\section{E. Definisi Operasional Variabel}

\section{Variabel Independen (X)}

\section{Kecerdasan Emosional $\left(X_{1}\right)$}

Menurut Golemen (2003) kecerdasan emosional adalah kemampuan lebih yang dimiliki seseorang dalam memotivasi diri,ketahanan dalam menghadapi kegagalan, mengendalikan emosi, dan menunda kepuasan serta mengatur keadaan jiwa.

\section{Indikator Kecerdasan emosional menurut Golemen (2003):}

a) Kesadaran Diri (Self Awareness), kemampuan untuk mengetahui apa yang dirasakan dalam dirinya dan menggunakannya untuk memadu pengambilan keputusan diri sendiri, memiliki tolak ukur yang realistis atas kemampuan diri sendiri dan kepercayaan diri yang kuat; b) Pengaturan Diri (Self Management), yaitu kemampuan seseorang dalam mengendalikan dan menangani emosinya sendiri sedemikian rupa sehingga berdampak positif pada pelaksanaan tugas, memiliki kepekaan pada kata hati, serta sanggup menunda kenikmatan sebelum tercapainya suatu sasaran dan mampu pulih kembali dari tekanan emosi; c) Motivasi (Self Motivation), yaitu hasrat yang paling dalam untuk menggerakkan dan menuntun diri menuju sasaran, membantu pengambilan inisiatif serta bertindak sangat efektif, dan mampu untuk bertahan dan bangkit dari kegagalan dan frustasi; d) Empati (Empathy/Social awareness), yaitu kemampuan merasakan apa yang dirasakan orang lain, mampu memahami perspektif orang lain dan menumbuhkan hubungan saling percaya, serta mampu menyelaraskan diri dengan berbagai tipe hubungan; e) Ketrampilan Sosial (Relationship Management), yaitu kemampuan untuk menangani emosi dengan baik ketika berhubungan sosial dengan orang lain, mampu membaca situasi dan jaringan sosial secara cermat, berinteraksi dengan lancar, menggunakan ketrampilan ini untuk mempengaruhi, memimpin, bermusyawarah, menyelesaikan perselisihan, serta bekerja sama dalam tim.

\section{Komunikasi $\left(\mathbf{X}_{2}\right)$}

Robbins (2006) bahwa komunikasi adalah proses penyampaian informasi, gagasan, fakta, pikiran dan perasaan dari satu orang ke orang lain. 


\section{Indikator Komunikasi menurut Rahmat (2000) :}

a) Pengertian, yaitu pemahaman dan penerimaan yang cermat terhadap isi pesan seperti yang dimaksud komunikator; b) Kesenangan, yaitu bahwa dengan berkomunikasi akan menimbulkan rasa senang dan puas bagi pihakpihak yang berkomunikasi; c) Mampu merubah sikap, artinya komunikasi yang dilakukan dapat mempengaruhi sikap peserta komunikasi sesuai dengan isi pesan; d) Hubungan sosial yang baik, maksudnya komunikasi bertujuan menumbuhkan dan mengembangkan hubungan sosial ke arah yang lebih baik; e) Tindakan, merupakan hasil akhir dari proses komunikasi yang efektif, menimbulkan tindakan nyata dan positif.

\section{Lingkungan Kerja $\left(\mathbf{X}_{3}\right)$}

Pembentukan lingkungan kerja yang mendukung kinerja akan menimbulkan kepuasan kerja bagi pekerja dalam suatu organisasi (Kegan,1993).

\section{Indikator Lingkungan Kerja Menurut Buchori (2000):}

a)Perlengkapan kerja yang meliputi : sarana dan prasarana penunjang kerja seperti, computer, mesin ketik, mesin pengganda, dan sebagainya; b) Pelayanan kepada pegawai/penyedia tempat ibadah, sarana kesehatan, koperasi, sampai pada kamar kecil; c) Kondisi kerja seperti ruang, suhu, penerangan, dan ventilasi udara; d) Hubungan personal yang meliputi kerjasama antara pegawai dan atasan.

\section{Variabel Dependen (Y) adalah Kinerja}

Irawan (2012) menyatakan bahwa kinerja (performance) adalah hasil kerja yang bersifat konkret, dapat diamati, dan dapat diukur.

Indikator Kinerja menurut Suranta (2002) :

a)Ketepatan waktu dalam menyelesaikan pekerjaan; b) Kemampuan bekerjasama dengan pegawai maupun orang lain; c) Kemampuan menyampaikan gagasan; d) Pengetahuan teknis pada pekerjaan.

\section{E. HASIL DAN ANALISIS}

Dalam penelitian ini item pertanyaan untuk setiap variabel baik dependen maupun independen lolos uji kualitas data dan uji asumsi klasik, sedangkan untuk uji regresi linear berganda, pengujian hipotesis dan koefisien determinasi adalah sebagai berikut: 
Analisis Regresi Linier berganda diperoleh persamaan:

$\mathrm{Y}=1,325+0,107 \mathrm{X}_{1}+0,387 \mathrm{X}_{2}+0,172 \mathrm{X}_{3}$

Persamaan regresi tersebut diatas dapat diartikan sebagai berikut:

a. Konstanta sebesar 1,325 satuan artinya jika kecerdasan emosi $\left(\mathrm{X}_{1}\right)$, komunikasi $\left(\mathrm{X}_{2}\right)$, lingkungan kerja $\left(\mathrm{X}_{3}\right)$ tidak ada perubahan, maka kinerja (Y) adalah sebesar 1,325 satuan.

b. Koefisien variabel kecerdasan emosi sebesar 0,107 artinya kinerja akan meningkat sebesar 0,107 satuan apabilavariabel kecerdasan emosi naik satu satuan dengan variabel komunikasi dan variabel lingkungan kerja bernilai tetap.

c. Koefisien variabel komunikasi sebesar 0,387 satuanartinya kinerja akan meningkat sebesar 0,387 satuan apabila variabel komunikasi naik satu satuan dengan kecerdasan emosi dan lingkungan kerja bernilai tetap.

d. Koefisien variabel lingkungan kerja sebesar 0,172 satuan artinya kinerja akan meningkat sebesar 0,172 satuan apabila variabellingkungan kerja naik satu satuan dengan kecerdasan emosi dan komunikasi bernilai tetap.

\section{Pengujian Hipotesis}

Untuk menguji hipotesis dalam penelitian ini digunakan analisis data berupa uji t dan uji f. Adapun hasilnya adalah sebagai beikut:

\section{a. Uji T}

Untuk menguji pengaruh kecerdasan emosional secara signifikan terhadap kinerja pegawai, menggunakan uji t.Diketahui bahwa variabel kecerdasan emosionalmemiliki nilai $t_{\text {hitung }}$ sebesar 1,074 sedangkan nilai $t_{\text {tabel }}$ sebesar 1,990 dengan demikian $t_{\text {hitung }}<\mathrm{t}_{\text {tabel }}$ yaitu $1,074<1,990$ serta nilai signifikan sebesar 0,286>0,05 yang menunjukkan bahwa Ho di diterima dan menolak Ha. Hal ini berartikecerdasan emosionaltidak berpengaruhpositif terhadap kinerja, dengan demikian hipotesis pertama ditolak.

Untuk menguji pengaruh komunikasi secara signifikan terhadap kinerja karyawan, menggunakan uji t. Diketahui bahwa variabel komunikasimemiliki nilai $t_{\text {hitungsebesar } 3,902}$ sedangkan nilai $t_{\text {tabel }}$ sebesar 1,990 dengan demikian $t_{\text {hitung }}>t_{\text {tabel }}$ yaitu 3,902>1.990 dengan taraf signifikansi sebesar 0,000. Nilai signifikansi berada di bawah 0,05 yang menunjukkan bahwa Ho di tolak dan menerima $\mathrm{Ha}$. Hal ini berartikomunikasiberpengaruhpositif terhadapkinerja, dengan demikian hipotesis kedua diterima.

Untuk menguji pengaruh lingkungan kerja secara signifikan terhadap kinerja pegawai.Diketahui bahwa variabel lingkungan kerja memiliki nilai $t_{\text {hitung }}$ sebesar 1,760 sedangkan nilai $t_{\text {tabel }}$ sebesar 1,990 dengan demikian $\mathrm{t}_{\text {hitung }}<\mathrm{t}_{\text {tabel }}$ yaitu $1,760<1,990$ serta nilai signifikan sebesar 0,082 lebih dari 
0,05 yang menunjukan bahwa Ho diterima dan menolak Ha. Hal ini berarti lingkungan kerja tidakberpengaruh positif terhadap kinerja, dengan demikian hipotesis ketiga ditolak.

b. Uji F

Untuk menguji pengaruhpositifkecerdasan emosional, komunikasi, dan lingkungan kerja secara bersama-sama terhadapkinerja karyawan, menggunakan uji $F$. Diketahui nilai $F_{\text {hitung }}$ pada model penelitian diketahui sebesar 7,002, sedangkan $F_{\text {tabel }}$ sebesar 2,717. Sehingga diketahui $F_{\text {hitung }}>F_{\text {tabel }}$ yaitu 7,002> 2,717 serta dengan taraf signifikansi sebesar 0,000. Nilai signifikansiberada di bawah 0,05 yang menunjukkan bahwa Ho ditolak dan menerima Ha. Hal ini berarti kecerdasan emosional, komunikasi, dan lingkungan kerja, secara bersama-sama berpengaruh positif terhadapkinerja, dengan demikian hipotesis keempat diterima.

\section{Koefisien Determinasi}

Berdasarkan koefisien determinasi diperoleh nilai Adjusted $\mathrm{R}^{2}$ sebesar 0,177 artinya $17,7 \%$ variabel kinerja pegawai dapat dijelaskan dari ketiga variabel independen yaitu kecerdasan emosional, komunikasi, dan lingkungan kerja. Selisihnya 82,3\% dijelaskan oleh sebab lain.

\section{F. PEMBAHASAN}

1. Hasil pengujian hipotesis pertama didapat hasil bahwa variabel kecerdasan emosi tidak berpengaruh terhadap kinerjapegawai. Hal ini dapat dilihat dari koefisien variabelkecerdasan emosisebesar 1,074 dengan taraf signifikan sebesar 0,286 lebih besar dari 0,05. Hal ini tidak sejalan dengan penelitian sebelumnya yang dilakukan oleh Penelitian Risma (2012) dengan judul Pengaruh Kecerdasan Emosional terhadap kinerja karyawan bahwa kecerdasan emosi berpengaruh terhadap kinerja karyawan. Pada penelitian ini Kecerdasan Emosional tidak berpengaruh secara positif terhadap kinerja pegawai dikarenakan kondisi yang ada terhadap ketiga kantor pelayanan publik, pegawai memiliki tugas pada setiap pekerjaannya yang berbeda-beda dan tingkat emosional yang berbedabeda. Sehingga fungsi dan tugas masing-masing dari setiap kantor sangat mempengaruhi tingkat emosional seseorang.

2. Hasil pengujian hipotesis kedua didapat hasil bahwa variabel komunikasi memiliki pengaruh terhadap kinerja pegawai. Hal ini dapat dilihat dari koefisien variabelkomunikasi 3,902 dengan taraf signifikan sebesar 0,000 kurang dari 0,05 . Hal ini sejalan dengan penelitian sebelumnya yang dilakukan olehPartini(2011) dengan judul Pengaruh Komunikasi, 
Pengaruh Kecerdasan Emosional, Komunikasi, Dan ... (Romantik dan Hermin)

Kepemimpinan, dan Kedisiplinan Kerja Terhadap Kinerja Karyawan. Komunikasi pada pegawai sudah baik dan harus dipertahankan agar kinerjanya dapat lebih baik.

3. Hasil pengujian hipotesis ketiga didapat hasil bahwa variabel lingkungan kerja tidak berpengaruh terhadap kinerja karyawan. Hal ini dapat dilihat dari koefisien variabel lingkungan kerja sebesar 1,760 dengan taraf signifikan sebesar 0,082 lebih dari 0,05. Hal ini tidak sejalan dengan penelitian sebelumnya yang dilakukan olehSetyaningsih (2010) dengan judul Pengaruh Kepemimpinan, Motivasi, Komunikasi, Dan Lingkungan Kerja Terhadap Terhadap Kinerja Pegawai. Lingkungan Kerja pada penelitian ini tidak berpengaruh secara positif terhadap kinerja pegawai dikarenakan kondisi lingkungan kerja yang sangat luas pada ketiga kantor pelayanan publik tersebut diantaranya fasilitas yang diberikan, dan hubungan yang terjalin antara pegawai maupun klien, sehingga pada lingkungan yang terdapat disana tidak semua pegawai dapat merasakan hal yang sama.

4. Hasil pengujian hipotesis keempat tentang Pengaruh kecerdasan emosi, komunikasi, dan lingkungan kerja, terhadap kinerja pegawai, hasil pengujian hipotesis keempat didapat hasil bahwa ketiga variabel tersebut memiliki pengaruh positif secara bersama-sama terhadap kinerja. Hal ini dapat dilihat dari nilai signifikansi sebesar $0,000<0,05$ atau $\mathrm{F}$ hitung $>\mathrm{F}$ tabel $(7,002>2,717)$.

\section{KESIMPULAN DAN IMPLIKASI}

\section{Kesimpulan}

1. Hasil penelitian ini menunjukan bahwa variabel kecerdasan emosi tidak berpengaruh terhadap kinerja.

2. Hasil penelitian ini menunjukan bahwa komunikasi berpengaruh terhadap kinerja.

3. Hasil penelitian ini menunjukkan bahwa variabel lingkungan kerja tidak berpengaruh terhadap kinerja.

4. Hasil penelitian ini menunjukan bahwa variabel kecerdasan emosi, komunikasi, dan lingkungan kerjasecara bersama-samaberpengaruh terhadap kinerja. 


\section{Implikasi}

Dalam upaya meningkatkan kinerja pegawai alangkah baiknya pada setiap instansi memperhatikan atau memberikan kebijakan-kebijakan tentang kecerdasan emosional pegawai dan melakukan pelatihan diantaranya yaitu pelatihan mengenai ESQ atau tes emotional intelligent, sehingga pegawai tidak hanya pandai secara kemampuan intelektual, tetapi pandai dalam mengatur emosi diri.Komunikasi pada instansi sudah terjalin dengan sangat baik. Instansi harus memperhatikan komunikasi-komunikasi yang ada di dalam instansi baik itu antar pegawai, dan antar departemen sehingga kinerja pegawai cenderung tetap dan meningkat, Dalam upaya meningkatkan kinerja pegawai pemerintah perlu memperhatikan lingkungan kerja diantaranya menyediakan fasilitas-fasilitas yang lebih memadai untuk mempermudah pegawai dalam pelaksanaan kinerjanya dan memberikan rasa nyaman.Untuk penelitian selanjutnya diharapkan untuk dapat menambah variabel lain yang dapat mempengaruhi kinerja pegawai khususnya pada kantor pelayanan publik, selain itu penggunaan sumber referensi baik berupa jurnal maupun literatur harus lebih banyak dan lengkap agar penelitian tentang kinerja bisa terus dikembangkan.

\section{DAFTAR PUSTAKA}

Ardana, Komang, Mujiati, Ni Wayan, Mudiartha Utama, I Wayan. 2012. Manajemen Sumber Daya Manusia. Yogyakarta: Graha Ilmu.

Campbell, J. P. \& Campbell, R. J. 1990.Productivity in Organizations.Oxford : Joshey Bass Publisher.

Ghozali, Imam. 2001. Aplikasi Analisis Multivariate dengan program SPSS. Semarang: Badan Penerbit Undip.

Ghozali, Imam. 2005, Aplikasi analisis multivariate dengan program SPSS, BP Universitas Diponegoro.

Golemen, D. (2003). Working with emotional intelligence Terjemahan, Jakarta: Gramedia Pustaka Utama.

Harold, Koontz. 1993. Manajemen cetakan kedelapan. Jakarta: Erlangga.

Liliweri, Alo, 2007, Dasar-dasar Komunikasi Kesehatan. Jakarta: Pustaka Pelajar

Mangkunegara, Anwar Prabu. 2000. Manajemen Sumber Daya Manusia Perusahaan. Bandung: Rosdakarya.

Mangkunegara, Anwar Prabu. 2007. Manajemen Sumber Daya Perusahaan, Cetakan ketujuh, Remaja Rosdakarya, Bandung. 
Mayer,J.D., Salovey, P. dan Caruso, D.R.1997. emotional IQ test, (CD room). Virtual knowledge.Nedham.

Nitiseminto, Alex. 1996. Manajemen Personalia. Cetakan kesembilan. Jakarta: penerbit Gholia Indonesia.

Rahmasari, Lisda. 2012. Pengaruh Kecerdasan Intelektual, Kecerdasan Emosi, dan Kecerdasan Spiritual Terhadap Kinerja Karyawan.Jurnal Majalah Ilmiah Informatika, Volume 03 Januari 2012.

Robbins, Stephen P., 2001, Perilaku Organisasi Jilid 1 Alih Bahasa: Handyana Pujaatmaka dan Benyamin Molan, Prenhallindo, Jakarta.

Robbins Stephen, 2006. Perilaku Organisasi, Jakarta: Prenhallindo.

Salovey, P. and Mayer, J. D. 1990. Emotional Intellegence, imagination.Cognition and personality. Volume 09.

Setyaningsih, 2010.Pengaruh Kepemimpinan, Motivasi, Komunikasi, dan Lingkungan Kerja Terhadap Kinerja Pegawai. Jurnal Manajemen Sumber Daya Manusia, volume 04 Juni, Fakultas Ekonomi Universitas Slamet Riyadi Surakarta.

Sugiyono, 2007.Metodologi Penelitian Administrasi. Jakarta: Grafindo.

Suwarto.2002, Perilaku Keorganisasian, Andi offset, Jakarta.

Umar, Husein, 2002, Riset Pemasaran dan Perilaku Konsumen. PT Gramedia Pustaka Utama.

Winardi, 2004.Motivasi dan Pemotivasian dalam Manajemen, Raja Grafindo Persada, Jakarta.

Wirawan. 2009. Evaluasi Kinerja Sumber Daya Manusia. Jakarta: Salemba Empat. 